\title{
激基缔合物器件中三重态-三重态湮灭的反常温度 依赖关系
}

赵茜, 汤仙童, 潘蓂亨, 许静, 屈芬兰, 熊祖洪 ${ }^{*}$

西南大学物理科学与技术学院, 重庆 400715

*联系人, E-mail: zhxiong@swu.edu.cn

2019-05-29 收稿, 2019-06-27 修回, 2019-06-28 接受, 2019-08-07 网络版发表

国家自然科学基金(11874305)资助

\begin{abstract}
摘要 激子型器件的电致发光磁效应(magneto-electroluminescence, MEL) 已经被研究得比较透彻, 而关于激基缔合 物型器件的MEL还鲜有报道. 本文制备了激基缔合物型有机发光二极管(organic light-emitting diodes, OLEDs), 并 测量了其在不同温度和注入电流下的MEL曲线. 实验发现, 激基缔合物型器件的MEL曲线由两部分组成: 系间窝越 过程决定的低场部分 $(|\boldsymbol{B}| \leqslant 50 \mathrm{mT})$ 和三重态-三重态湮灭(triplet-triplet annihilation, TTA)过程决定的高场部分(50 $\mathrm{mT}<|\boldsymbol{B}| \leqslant 300 \mathrm{mT}$ ), 表明在不同温度和注入电流下, 激基缔合物型器件中始终存在可以产生延迟苂光的 TTA过程. 然而在某一固定注入电流下, 激基缔合物型器件的TTA过程具有与激子型器件相反的温度依赖关系, 即激子型器 件的TTA过程在低温下发生并随温度降低而增强，但激基缔合物型器件的TTA过程在室温下发生并随温度降低而 减弱。激基缔合物型器件中TTA过程的这种反常温度依赖关系很好地弥补了以往只有在低温下才能利用TTA过程 来提高器件发光效率的这一不足. 通过分析器件的能级结构、电流-电压-发光特性曲线和光谱可知, 激基缔合物 型器件中TTA过程的反常温度依赖关系与三重态激基缔合物较长的寿命和低温对激基缔合物形成的抑制有关. 本 文的研究结果对提高OLEDs的发光效率具有一定的指导意义.
\end{abstract}

关键词 激基缔合物, 激子, 三重态-三重态湮灭, 电致发光磁效应

自1954年Förster和Kasper ${ }^{[1]}$ 在芘的正己烷溶液中 发现激基缔合物以来，激基缔合物就因其具有广泛的 应用引起了人们的大量关注. 激基缔合物是指处于激 发态的分子与基态下的同种分子进行相互作用，从而 形成的激发态缔合物. 它因具有较长的发光寿命被应 用于激光器件 ${ }^{[2]}$. 除此之外, 它的发光相对于自身的单 体分子出现红移和展宽 ${ }^{[3]}$, 所以也被用来制备化学传感 器、生物探测器和白光有机发光二极管(organic lightemitting diodes, OLEDs $)^{[4]}$. 虽然激基缔合物具有许多 优点, 但是到目前为止研究者们对它的研究手段还很 少, 以至于它的很多微观机制都还不清楚.
最近, 电致发光磁效应(magneto-electroluminescence, MEL)作为一个有用的工具, 可以用来研究 OLEDs中激发态的动力学过程 ${ }^{[57]}$. 这是因为, 一个外 加磁场可以通过影响OLEDs中与自旋相关的微观过程 来改变单重态与三重态之间的数量平衡和器件的电致 发光强度 ${ }^{[8 \sim 10]}$. 这些与自旋相关的微观过程包括系间宫 跃(intersystem crossing, ISC) ${ }^{[11]}$ 、反系间宫跃 ${ }^{[12]}$ 、单重 态裂变和三重态-三重态湮灭(triplet-triplet annihilation,

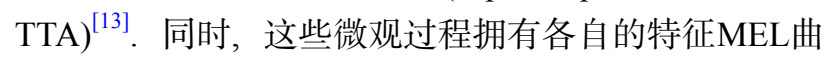
线, 并且受电荷注人/复合以及激发态的浓度和寿命影 响 ${ }^{[14]}$. 众所周知, 注人电流可以影响激发态的浓度, 温

引用格式: 赵茜, 汤仙童, 潘㪦亨, 等. 激基缔合物器件中三重态-三重态湮灭的反常温度依赖关系. 科学通报, 2019, 64: 2514-2522 Zhao X, Tang X T, Pan R H, et al. Abnormal temperature dependence of triplet-triplet annihilation in excimer-based devices (in Chinese). Chin Sci Bull, 2019, 64: 2514-2522, doi: 10.1360/TB-2019-0111 
度可以影响电荷注人/复合和激发态的寿命 ${ }^{[15]}$. 因此, 研究电流或温度依赖的MEL曲线可以有效地分析激基 缔合物型OLEDs中激发态的行为.

本工作通过测量和对比激基缔合物型和激子型 OLEDs的MEL曲线, 研究了激基缔合物型器件中激发 态演化的微观机制. 室温下, 随着磁场强度增大, 虽然 这两种器件的MEL曲线的低场部分 $(|\boldsymbol{B}| \leqslant 50 \mathrm{mT})$ 都因 磁场对器件中ISC过程的抑制而快速上 升 $^{[16]}$, 但是高场 部分 $(50 \mathrm{mT}<|\boldsymbol{B}| \leqslant 300 \mathrm{mT}$ ) 截然相反. 激子型器件的高 场部分因磁场对ISC过程的抑制作用趋于饱和而缓慢 上升 ${ }^{[7]}$, 而激基缔合物型器件的高场部分却快速下降. 高场下降只发生在激基缔合物型器件中是因为激基缔 合物较长的寿命 ${ }^{[2,17,18]}$ 在器件中引起了室温下的 TTA过 程 ${ }^{[18-20]}$. 随着温度从 $300 \mathrm{~K}$ 降低到 $20 \mathrm{~K}$, 激基缔合物型 器件中TTA过程的强度和低场部分的幅值都表现出与 激子型器件相反的温度依赖关系, 即激子型器件的 TTA过程在低温下发生并逐渐增强，同时低场部分的 幅值逐渐减小; 而激基缔合物型器件的TTA过程逐渐 减弱，同时低场部分的幅值逐渐增大. 这是因为，温度 降低阻碍了激发态与基态相互作用形成激基缔合

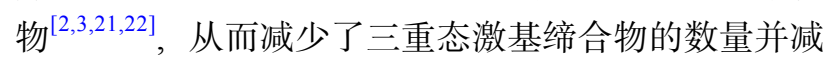
弱了 TTA过程的强度; 又因为TTA过程的减弱会导致 器件的电致发光强度减弱 ${ }^{[23]}$, 所以低场部分的幅值增 大. 本文在外加磁场的辅助下深人地研究了激基缔合 物型器件的TTA过程, 从而丰富了器件中激发态演化 的微观机制.

\section{1 器件的制备与测量}

本文采用超高真空有机分子束沉积技术，制备了 两种激基缔合物型OLEDs和一种作为参考的激子型 OLEDs. 第一种激基缔合物型OLEDs命名为器件1(device 1, Dev.1), 其结构为ITO/poly(3,4-ethylenedioxythiophene):poly(styrenesulfonate)(PEDOT:PSS)(40 nm) /4,4',4"-tris( $N$-3-methylphenyl- $N$-phenylamino)triphenylamine $(m$-MTDATA $)(60 \mathrm{~nm}) / 1,3$-bis $(N$-carbazolyl)benzene $(\mathrm{mCP})(10 \mathrm{~nm}) / 2,4,6$-tris[3-(diphenylphosphinyl)phenyl]-1,3,5-triazine(PO-T2T)(30 nm)/tris(8-hydroxy-quinolinato)aluminum $\left(\mathrm{Alq}_{3}\right)(60 \mathrm{~nm}) / \mathrm{LiF}(1 \mathrm{~nm}) / \mathrm{Al}(120 \mathrm{~nm})$. 激子型OLEDs命名为器件 2 (device 2, Dev.2), 其结构为 ITO/PEDOT:PSS(40 nm) $/ N, N^{\prime}$-di(naphthalen-1-yl)- $N, N^{\prime}$ diphenylbenzidine(NPB) $(60 \mathrm{~nm}) / \mathrm{Alq}_{3}(80 \mathrm{~nm}) / \mathrm{LiF}(1 \mathrm{~nm}) /$ $\mathrm{Al}(120 \mathrm{~nm})$. 第二种激基缔合物型OLEDs命名为器件3 (device 3, Dev.3), 其结构为ITO/PEDOT:PSS $(40 \mathrm{~nm}$ ) $/ m$ $\operatorname{MTDATA}(60 \mathrm{~nm}) / \mathrm{mCP}(15 \mathrm{~nm}) / \mathrm{PO}-\mathrm{T} 2 \mathrm{~T}(30 \mathrm{~nm}) / \mathrm{Alq}_{3}$ $(60 \mathrm{~nm}) / \mathrm{LiF}(1 \mathrm{~nm}) / \mathrm{Al}(120 \mathrm{~nm})$. 带有ITO阳极的玻璃衬 底从商业公司购买. 在把衬底放人真空沉积系统进行 有机分子束沉积之前, 首先用去离子水和清洗液(Decon 90, 浓度为 $4 \%$ ) 对其正反面各清洗 200 遍, 并在超声 清洗仪中进行水浴超声(水浴温度为 $60^{\circ} \mathrm{C}$ ). 然后用丙酮 和无水乙醇分别对衬底进行有机杂质的溶解和脱水处 理. 随后, 采用旋涂法在衬底上制备PEDOT:PSS层. 最 后, 将衬底传人真空系统 $\left(10^{6} \mathrm{~Pa}\right)$ 中进行有机功能层的 蒸镀. 在蒸镀有机功能层时, 有机材料的生长速率和各 功能层的厚度采用INFICON公司的膜厚检测仪(XTM/ 2)进行原位监测.

样品制备完成后，迅速将其固定在一套高真空闭 循环冷却系统(Janis: CCS-340S, 温度范围: 15 310 K) 的冷头上. 然后将装有样品的冷却系统放人电磁铁 (Lakeshore: EM647)之间, 并且使样品表面平行于外磁场. 该测量系统由计算机通过Labview软件对系统中的电 磁铁(最大磁场为 $1 \mathrm{~T}$ )、霍尔探头、Keithley 2400 万用 表、硅光电探头以及Keithley 2000万用表进行实时监 控. 其中, Keithley 2400 不但为器件提供偏压, 还测量 流过器件的电流. 硅光电探头测量器件的电致发光强 度并通过Keithley 2000读取. Lakeshore 421高斯计可 测出磁场的大小. 在整个测量过程中, 器件均处于恒压 偏置状态.

\section{2 实验结果与分析}

\section{1 器件结构及其发光表征}

图1(a)为Dev.1的能级结构. 其中, 作为空穴传输层 的 $m$-MTDATA和mCP具有较高的空穴迁移率 $\left(5.1 \times 10^{-4}\right.$ 和7.2 $\left.\times 10^{-4} \mathrm{~cm}^{2} \mathrm{~V}^{-1} \mathrm{~s}^{-1}\right)^{[7,24]}$. 同时, 作为电子传输层的 $\mathrm{PO}-\mathrm{T} 2 \mathrm{~T}$ 和 $\mathrm{Alq}_{3}$ 分别具有较高的电子迁移率 $(4.4 \times$ $\left.10^{-3} \mathrm{~cm}^{2} \mathrm{~V}^{-1} \mathrm{~s}^{-1}\right)^{[24]}$ 和较高的电子亲和能 ${ }^{[25]}$. 又因为 $\mathrm{mCP}$ 层的厚度较薄且具有传输空穴的咔唑基团 ${ }^{[26-29]}$, 所以从 阳极注人的空穴穿过 $m$-MTDATA和mCP层后到达PO$\mathrm{T} 2 \mathrm{~T}$ 层, 而从阴极注人的电子穿过 $\mathrm{Alq}_{3}$ 层后被阻挡在 $\mathrm{PO}-$ $\mathrm{T} 2 \mathrm{~T}$ 层. 因此, 电子和空穴在PO-T2T层复合形成激发态, 然后激发态退激辐射并发出苂光. 作为发光层的PO$\mathrm{T} 2 \mathrm{~T}$ 的化学结构见图1(b). 图1(c)及其插图为Dev.1, Dev. 2 和Dev. 3 的电流-电压曲线和电致发光强度-电流曲 线. 可以看出, 它们都表现出二极管特性, 并且其发光强 


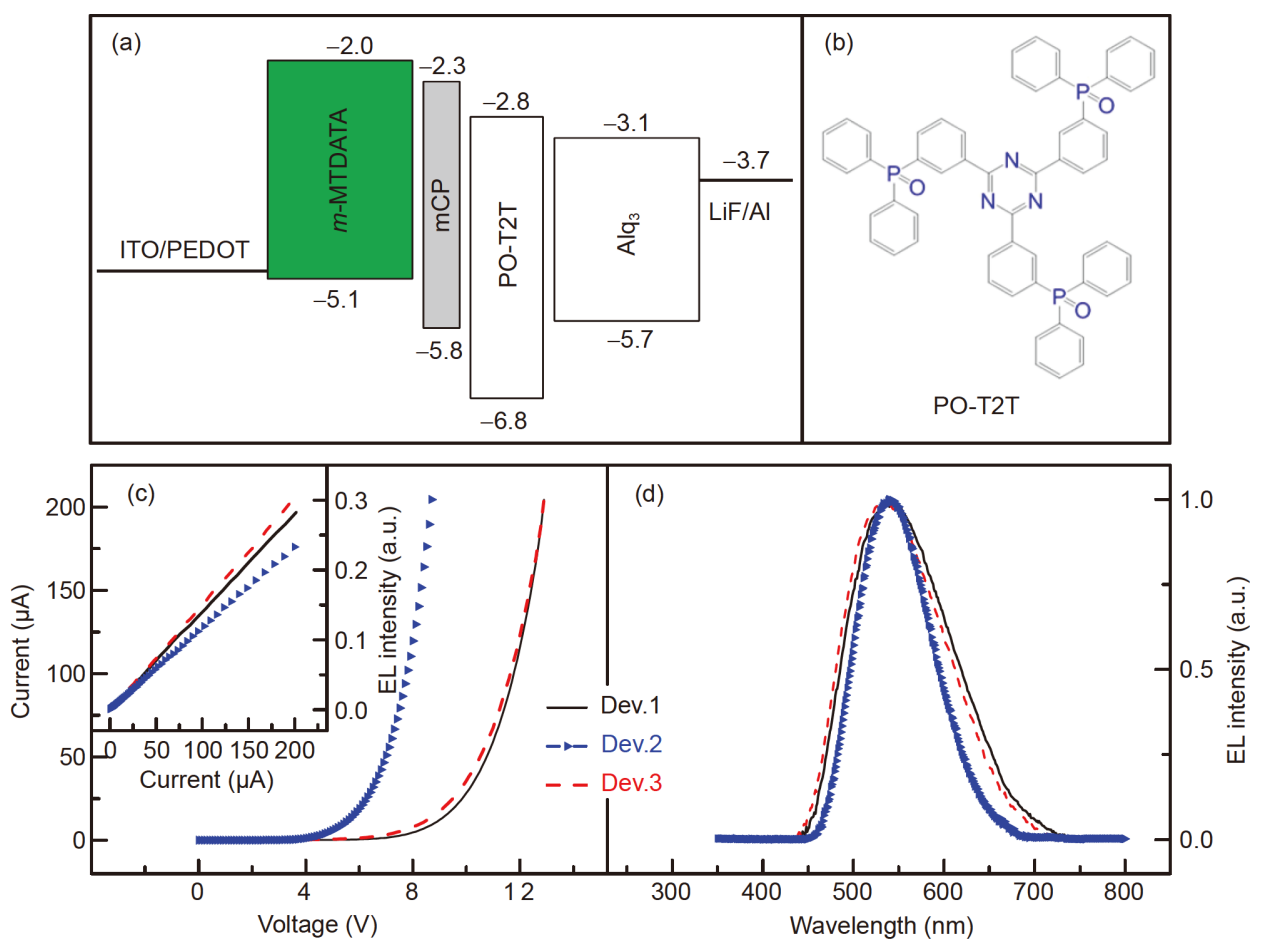

图 1 (网络版彩色)器件的能级结构和发光特性曲线. (a) Dev.1的能级结构; (b) PO-T2T的化学结构; (c) Dev.1, Dev.2和Dev.3的电流-电压曲线和 发光-电流曲线; (d) Dev.1, Dev.2和Dev.3的归一化电致发光光谱

Figure 1 (Color online) Energy level structure and luminescence characteristics of devices. (a) Energy level structure of Dev.1; (b) chemical structure of PO-T2T; (c) current-voltage and brightness-current curves of Dev.1, Dev.2 and Dev.3; (d) normalized EL spectra of Dev.1, Dev.2 and Dev.3

度随注人电流增大而增强. 随后, 还测量了这3种器件在 室温下的电致发光光谱(图1(d)). 明显地，Dev.1和Dev.3 的光谱几乎重叠. 虽然Dev. 1 和Dev. 3 的发光峰位 $(\sim 525 \mathrm{~nm})$ 与Dev.2( $540 \mathrm{~nm})$ 接近, 但是它们的光谱明显 比Dev.2宽. 因为PO-T2T最低单重态激基缔合物的发光 峰位为 $525 \mathrm{~nm}^{[30]}$, 并且其光谱相对PO-T2T最低单重态 激子(405 nm)出现红移和展宽 ${ }^{[31]}$, 所以Dev.1和Dev.3的 发光来自PO-T2T最低单重态激基缔合物的退激辐射.

\section{2 室温下不同注入电流时器件的MEL}

首先对比Dev.1和Dev.2的MEL. 图2(a)和(b)分别为 Dev.1和Dev.2在室温下不同注人电流时电致发光强度 随磁场强度的变化关系. 可以看出, 这些MEL曲线都分 为低场部分和高场部分; 随着磁场强度增大，Dev.1和 Dev.2的低场部分都快速上升. 据文献[11]报道, 这是因 为磁场对器件中ISC过程的抑制作用. 同时, Dev.1和 Dev.2在同一磁场强度下，低场部分的幅值都随注人电 流增大而减小. 为了解释低场部分的这种电流依赖关 系，定义MEL的低场效应(low-field effect，LFE)为
$\operatorname{LFE}=\operatorname{MEL}(50 \mathrm{mT})-\operatorname{MEL}(0)$. 其中，MEL的定义式为 $\mathrm{MEL}=\Delta \mathrm{EL} / \mathrm{EL}=[\mathrm{EL}(B)-\mathrm{EL}(0)] / \operatorname{EL}(0)$, 而 $\operatorname{EL}(B)$ 和 $\operatorname{EL}(0)$ 分别为有磁场时和无磁场时器件的电致发光强度. 50 $\mathrm{mT}$ 下, 随着注人电流增大, 虽然 $\mathrm{EL}$ 和 $\Delta \mathrm{EL}$ 都增强, 但是 因为EL增加得比 $\Delta E L$ 更快, 所以 $\operatorname{MEL}(50 \mathrm{mT})$ 减小. 因 此, Dev.1和Dev.2的LFE都随注人电流增大而减小. 虽 然Dev.1和Dev.2的低场部分具有相似的ISC线形和电流 依赖关系, 但是高场部分却截然相反. 在所有注人电流 下，随着磁场强度增大, Dev.2的高场部分缓慢上升, 而 Dev.1的高场部分快速下降，并且随注人电流增大下降 更明显. 为了解释这两种不同的高场部分, 研究了 Dev.1和Dev.2中的微观机制(图2(c), (d)). 对于Dev.2, 分 别由阳极和阴极注人的空穴和电子在有机材料中传输, 并在库仑吸引作用下相互靠近从而复合形成 $25 \%$ 的单 重态极化子对(singlet polaron pairs, $\mathrm{PP}_{1}$ )和 $75 \%$ 的三重 态极化子对(triplet polaron pairs, $\left.\mathrm{PP}_{3}\right)^{[32]}$. 同时, 部分 $\mathrm{PP}_{1}$ 和 $\mathrm{PP}_{3}$ 也会分别以 $\mathrm{d}_{\mathrm{S}}$ 和 $\mathrm{d}_{\mathrm{T}}$ 解离成自由的载流子 ${ }^{[33]}$. 随着 电子与空穴之间距离的继续缩短, $\mathrm{PP}_{1}$ 和 $\mathrm{PP}_{3}$ 分别以 $\mathrm{k}_{\mathrm{S}}$ 和 $\mathrm{k}_{\mathrm{T}}$ 形成单重态激子 $\left(\mathrm{S}_{1}\right)$ 和三重态激子 $\left(\mathrm{T}_{1}\right)$, 并且只有 $\mathrm{S}_{1}$ 

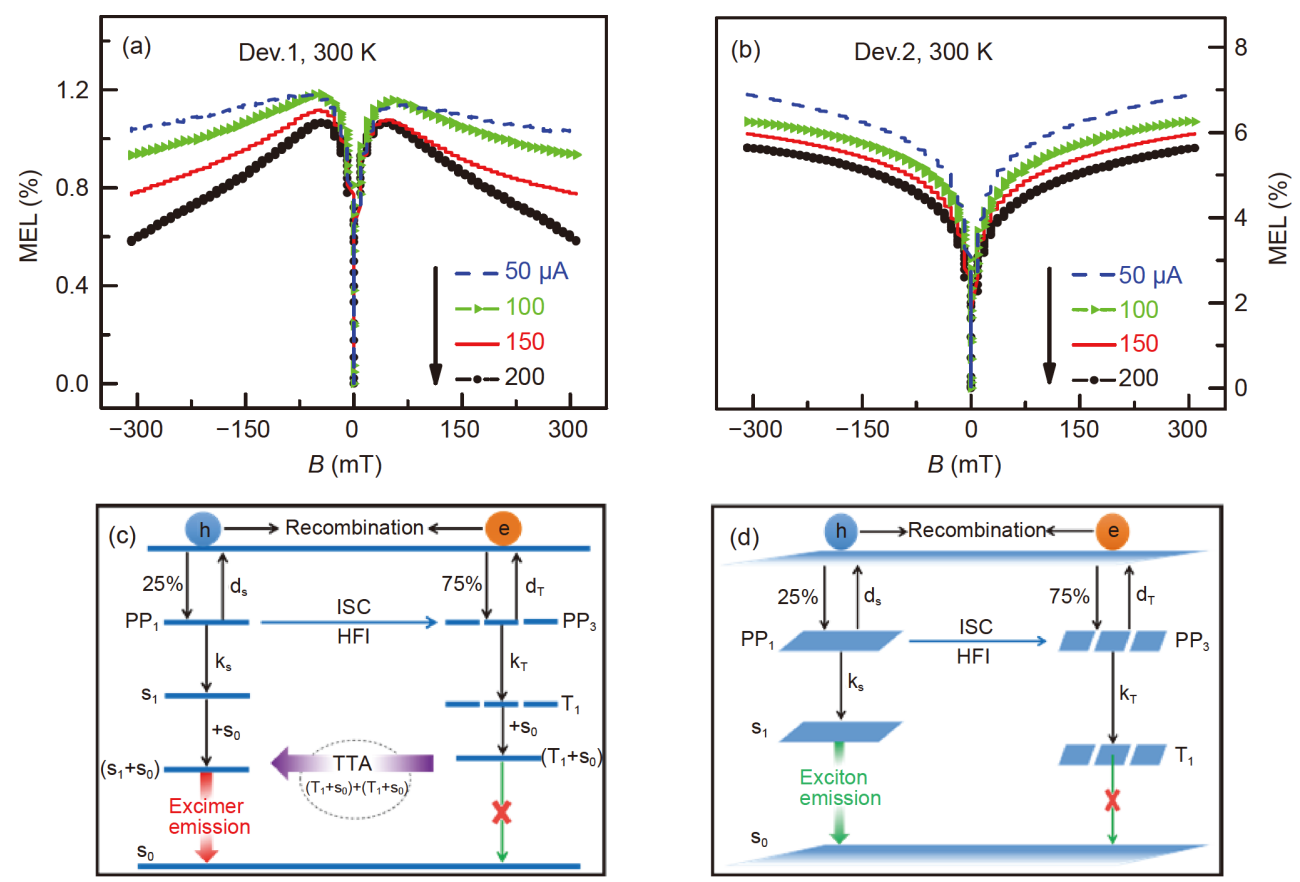

图 2 (网络版彩色) $300 \mathrm{~K}$ 下不同注人电流时Dev.1和Dev.2的MEL曲线以及器件的微观机理图. (a) Dev.1的MEL曲线; (b) Dev.2的MEL曲线; (c) Dev.1的微观机理图; (d) Dev.2的微观机理图

Figure 2 (Color online) Current-dependent MEL curves of Dev.1 and Dev.2 at $300 \mathrm{~K}$ and microscopic mechanisms in devices. (a) MEL curves of Dev.1; (b) MEL curves of Dev.2; (c) microscopic mechanisms in Dev.1; (d) microscopic mechanisms in Dev.2

能以退激辐射的方式发出苂光 ${ }^{[11]}$. 因为PP态中电子与 空穴之间的距离较远，所以 $\mathrm{PP}_{1}$ 与 $\mathrm{PP}_{3}$ 之间的自旋交换 作用较弱, 从而 $\mathrm{PP}_{1}$ 很容易在超精细相互作用下通过 ISC过程变成 $\mathrm{PP}_{3}{ }^{[11]}$. 当加人外磁场时, 如果外磁场强度 大于内部磁相互作用, 则外磁场能增强三重态能级的 Zeeman分裂，从而抑制 $\mathrm{PP}_{1}$ 向 $\mathrm{PP}_{3}$ 的转化，即抑制ISC过 程 ${ }^{[16]}$. 因为 ISC过程被外磁场抑制, 所以 $\mathrm{PP}_{1}$ 的数量增加, 从而引起 $\mathrm{S}_{1}$ 的数量增加以及器件的电致发光强度增强, 导致低场部分快速上升 ${ }^{[16]}$. 当外加磁场继续增大, 磁场 对ISC过程的抑制作用趋于饱和，所以Dev.2的高场部 分缓慢上升 ${ }^{[7]}$. 虽然Dev.1中的微观机制与Dev.2大体相 似, 但是Dev.1中的 $\mathrm{S}_{1}$ 和 $\mathrm{T}_{1}$ 会与基态 $\left(\mathrm{S}_{0}\right)$ 相互作用分别形 成单态激基缔合物 $\left(\mathrm{S}_{1}+\mathrm{S}_{0}\right)$ 和三重态激基缔合物 $\left(\mathrm{T}_{1}+\right.$

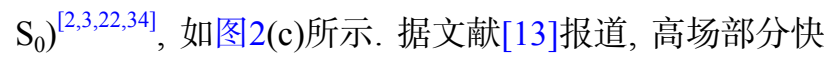
速下降是因为磁场抑制了器件中的TTA过程. 又因为 $\mathrm{T}_{1}$ 很容易被声子等热噪声淬灭, 从而导致其寿命缩短, 所 以TTA过程很难在室温下发生在Dev.2 中 $^{[13]}$. 但是因为 $\left(\mathrm{T}_{1}+\mathrm{S}_{0}\right)$ 具有比 $\mathrm{T}_{1}$ 更长的寿命 ${ }^{[2,17,18]}$, 所以Dev.1 中就有足 够多的 $\left(\mathrm{T}_{1}+\mathrm{S}_{0}\right)$ 来发生室温下的 TTA过程 $\left(\left(\mathrm{T}_{1}+\mathrm{S}_{0}\right)+\left(\mathrm{T}_{1}\right.\right.$ $\left.\left.+\mathrm{S}_{0}\right) \rightarrow\left(\mathrm{S}_{1}+\mathrm{S}_{0}\right)+2 \mathrm{~S}_{0}\right)^{[18-20]}$, 如图2(c)所示. 关于TTA过程 的强度随注人电流增大而增强, 这是因为载流子的数
量随注人电流增大而增加, 从而导致 $\left(\mathrm{T}_{1}+\mathrm{S}_{0}\right)$ 的数量 增加.

\section{3 相同注入电流下不同温度时器件的MEL}

为了进一步研究激基缔合物型器件中激发态演化 的微观机制, 还测量了Dev.1和Dev.2在 $200 \mu \mathrm{A}$ 下不同温 度时的MEL曲线(图3(a), (b)). 在降温的过程中, 虽然 Dev.1和Dev.2的低场部分始终表现出ISC线形, 但是这 两种器件的LFE关于温度具有相反的依赖关系. 为了 分析这两种相反的温度依赖关系, 比较了Dev.1和Dev.2 在200 $\mu \mathrm{A}$ 下不同温度时的 LFE(图3(c)). 随着温度从 300 K降低到 20 K, Dev.2的LFE从 $4.29 \%$ 减小到 $2.14 \%$, 而Dev.1的LFE从 $1.06 \%$ 增大到 $1.27 \%$. 因为LFE与EL和 $\Delta \mathrm{EL}$ 都有关, 并且TTA过程会影响EL和 $\Delta \mathrm{EL}$, 所以在解 释Dev. 1 和Dev. 2 中LFE的这两种相反的温度依赖关系 前, 要先分析TTA过程的温度依赖关系. 随着温度降低, Dev.2的高场部分从随磁场强度增大而缓慢上升逐渐 变为快速下降, 而Dev.1的高场部分一直随磁场强度增 大而快速下降. 为了量化分析这两种器件的高场部分, 定义高场效应(high-field effect, HFE)为HFE=MEL(300 $\mathrm{mT})-\operatorname{MEL}(50 \mathrm{mT})$. Dev.1和Dev.2在 $200 \mu \mathrm{A}$ 下不同温度 

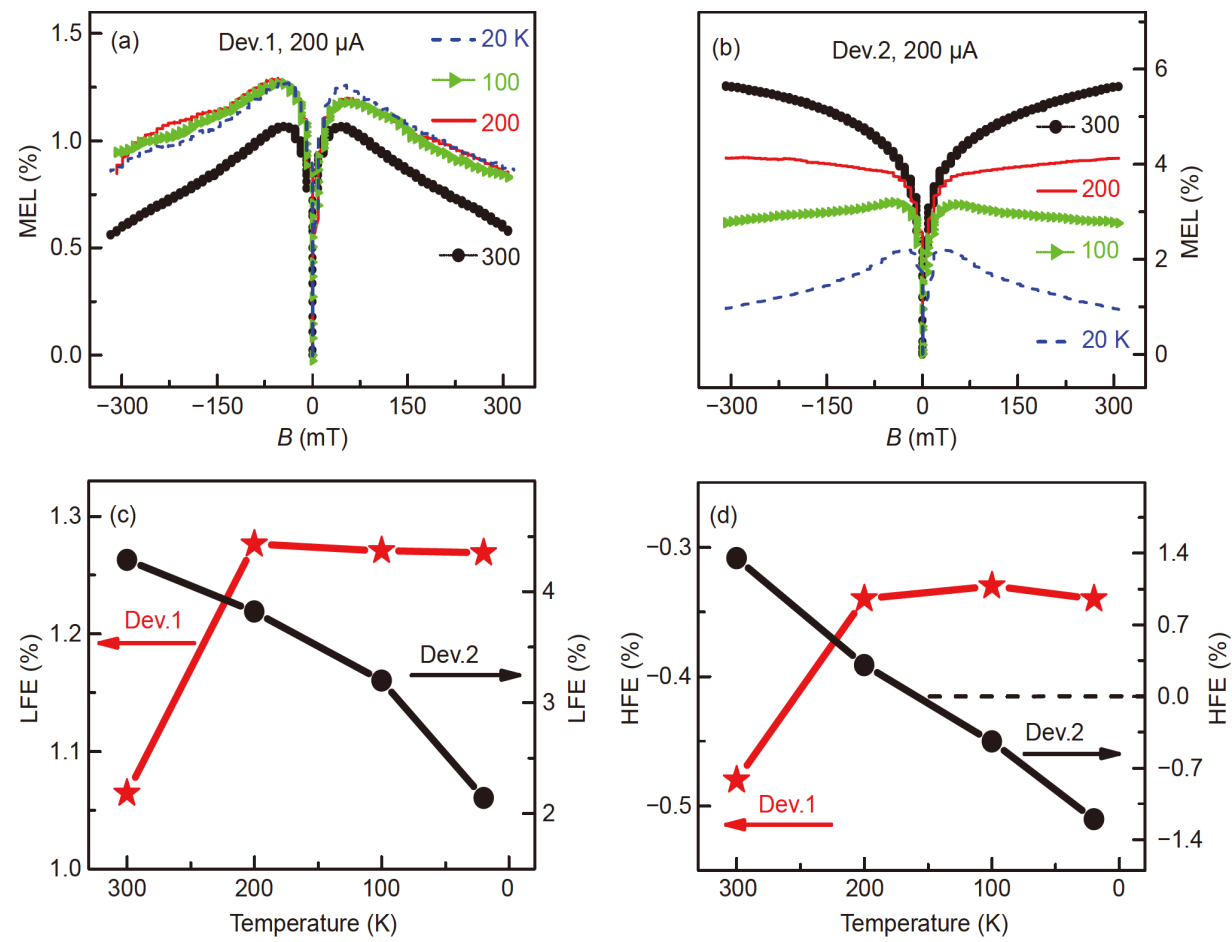

图 3 (网络版彩色) $200 \mu \mathrm{A}$ 下不同温度时Dev.1和Dev.2的MEL曲线, LFE值和HFE值. (a) Dev.1的MEL曲线; (b) Dev.2的MEL曲线; (c) Dev.1和 Dev.2的LFE值; (d) Dev.1和Dev.2的HFE值

Figure 3 (Color online) MEL curves, LFE and HFE values of Dev.1 and Dev.2 at injection current of $200 \mu \mathrm{A}$. (a) MEL curves of Dev.1; (b) MEL curves of Dev.2; (c) LFE values of Dev.1 and Dev.2; (d) HFE values of Dev.1 and Dev.2

时的HFE见图3(d). 对于Dev.2, HFE随温度降低逐渐从 $1.35 \%$ 减小到 $-1.20 \%$, 表示TTA过程在低温下发生并随 温度降低而增强. 这是因为温度降低减弱了声子等热 噪声对 $\mathrm{T}_{1}$ 的淬灭作用, 导致 $\mathrm{T}_{1}$ 的寿命延长, 从而在 Dev.2中发生了TTA过程 ${ }^{[13]}$. 但是Dev.1的HFE随着温度 降低逐渐从 $-0.49 \%$ 增大到 $-0.34 \%$, 表示器件中TTA过 程的强度逐渐减弱. 这是因为载流子迁移率的降低阻 碍了 $\mathrm{T}_{1}$ 与 $\mathrm{S}_{0}$ 相互作用形成 $\left(\mathrm{T}_{1}+\mathrm{S}_{0}\right)^{[2,3,21,22]}$, 从而减少了 $\left(\mathrm{T}_{1}+\mathrm{S}_{0}\right)$ 的数量. 又因为 TTA过程可以将不能退激辐射 的三重激发态转换为能退激辐射的单重激发态，所以 器件的电致发光强度与TTA过程的强度成正比 ${ }^{[23]}$. 因 此, 随着温度降低, Dev.2的电致发光强度增强, 而 Dev.1的电致发光强度减弱. 现在可以利用MEL的定义 式来解释Dev.1和Dev.2中LFE的这两种相反的温度依 赖关系. $50 \mathrm{mT}$, 对于Dev.2, 虽然 $\Delta$ EL 和EL都随温度 降低而增强, 但是因为EL增加得比 $\Delta E L$ 更快, 所以MEL $(50 \mathrm{mT})$ 减小, 即LFE减小. 相反, 对于Dev.1, 虽然 $\Delta$ EL 和 $\mathrm{EL}$ 都随温度降低而减弱, 但是因为 $\mathrm{EL}$ 减小得比 $\Delta \mathrm{EL}$ 更 快, 所以MEL(50 mT)增大, 即LFE增大.

\section{4 低温下不同注入电流时器件的MEL}

为了验证Dev.1中LFE和TTA过程与Dev.2具有相 反的温度依赖关系，测量了 $20 \mathrm{~K}$ 下不同注人电流时这 两种器件的MEL曲线(图4(a), (b)). 明显地, Dev.1和 Dev.2的低场部分均表现出与室温相似的ISC线形和电 流依赖关系. 同时, 它们的高场部分都因磁场对器件中 TTA过程的抑制而快速下降. 为了分析Dev.1和Dev. 2 在 低温下的LFE和TTA过程, 比较了 $20 \mathrm{~K}$ 下不同注人电流 时这两种器件的LFE和HFE(图4(c), (d)). 从图4(c)可以 看出, 当注人电流为 $50 \mu \mathrm{A}$ 时, Dev. 2 在低温下的LFE (2.39\%)小于其在室温下的 $\operatorname{LFE}(5.44 \%$, 图 1(b)), 而 Dev. 1在低温下的LFE(1.48\%)大于其在室温下的LFE $(1.18 \%$, 图1(a)). 在注人电流为 100,150 和 $200 \mu \mathrm{A}$ 时, 也 具有相似的比较关系. 这与Dev. 1 中LFE的反常温度依 赖关系一致. 同时, 从图4(d)可以看出, 当注人电流为 $50 \mu \mathrm{A}$ 时, Dev. 在低温下的HFE(-0.68\%)小于其在室温 下的HFE(1.45\%, 图 1(b)), 而Dev.1在低温下的HFE $(-0.03 \%)$ 大于其在室温下的 $\operatorname{HFE}(-0.14 \%$, 图1(a)). 其 

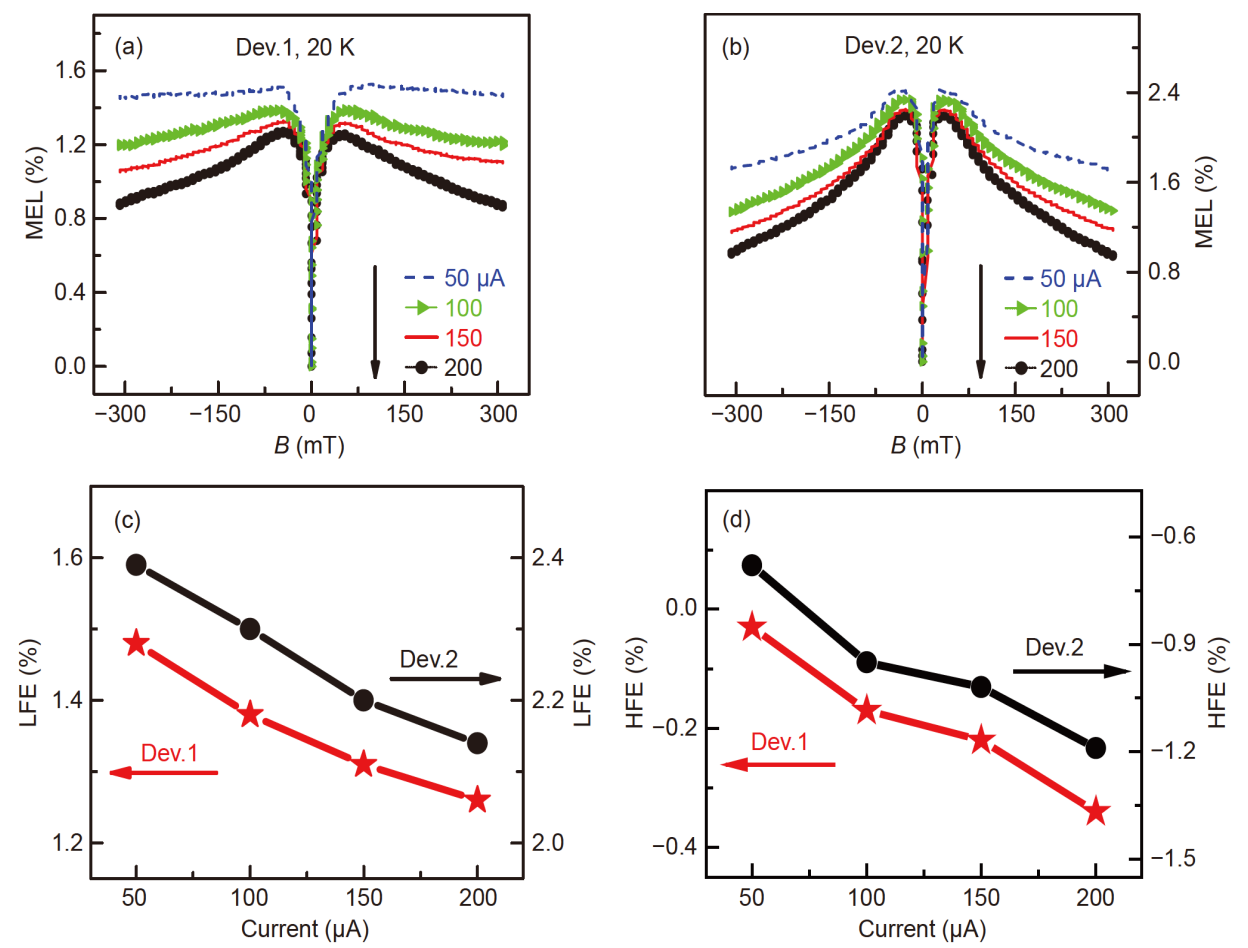

图 4 (网络版彩色) $20 \mathrm{~K}$ 下不同注人电流时Dev.1和Dev.2的MEL曲线, LFE值和HFE值. (a) Dev.1的MEL曲线; (b) Dev.2的MEL曲线; (c) Dev.1和 Dev.2的LFE值; (d) Dev.1和Dev.2的HFE值

Figure 4 (Color online) MEL curves, LFE and HFE values of Dev.1 and Dev.2 at different injection currents at 20 K. (a) MEL curves of Dev.1; (b) MEL curves of Dev.2; (c) LFE values of Dev.1 and Dev.2; (d) HFE values of Dev.1 and Dev.2

他注人电流下的比较关系与之相似，表示Dev.2在低温 下的TTA过程强于室温，而Dev.1在低温下的TTA过程 弱于室温. 因此, 这两种器件在 $20 \mathrm{~K}$ 下不同注人电流时 的MEL曲线进一步证明了Dev.1中LFE和TTA过程与 Dev.2具有相反的温度依赖关系.

\subsection{Dev.3的MEL}

因为Dev. 3 的发光也是来自PO-T2T最低单重态激 基缔合物, 所以为了验证Dev.1中LFE和TTA过程的反 常温度依赖关系，还测量并分析了Dev.3的MEL. 首先， 测量了Dev.3在室温下不同注人电流时的MEL曲线(图5 (a)). 在所有注人电流下, Dev.3的高场部分也随着磁场 强度增大而快速下降, 表示在Dev.3中也发生了室温下 的TTA过程. 随后，测量了Dev.3在 $200 \mu \mathrm{A}$ 下不同温度 时的MEL曲线(图 5(b)). 在降温的过程中, Dev.3的低场 部分和高场部分始终分别表现出与Dev.1相似的ISC线 形和高场下降. 为了量化分析Dev.3的低场部分和高场 部分的温度依赖关系, 比较了 $200 \mu \mathrm{A}$ 下不同温度时的 LFE和HFE(图5(c)). 随着温度降低，Dev.3的LFE从
1.06\%增大到 $1.18 \% ，$ HFE从-0.78\%增大到 $-0.61 \%$. 表 明Dev. 3 的LFE和TTA过程具有与Dev. 1 相似的温度依 赖关系, 即随着温度降低, LFE增大并且TTA过程减弱. 最后，还测量了Dev.3在低温下不同注人电流时的MEL 曲线(图5(d)). 当注人电流为 $50 \mu \mathrm{A}$ 时, Dev.3在低温下的 LFE $(1.33 \%$ ，图 5(d))大于其在室温下的值 $(1.29 \%$ ，图 5 (a)), 并且 $\operatorname{HFE}(-0.28 \%$, 图 $5(\mathrm{~d}))$ 也大于其在室温下的值 $(-0.34 \%$, 图 5(a)). 在注人电流为 100,150 和 $200 \mu \mathrm{A}$ 时也 可以发现相似的比较关系, 证明Dev.3中LFE和TTA过 程具有反常温度依赖关系，且与Dev.1相似。因此， Dev.3在室温、降温、低温时的MEL曲线都表现出与 Dev.1相似的规律，进一步证明了Dev.1中LFE和TTA过 程的反常温度依赖关系.

\section{3 结论}

本文通过测量和分析激基缔合物型OLEDs的 MEL曲线, 研究了器件中TTA过程的反常温度依赖关 系。室温下，在激基缔合物型器件中发现了通常在低 温下才会发生的TTA过程，这是因为 $\left(\mathrm{T}_{1}+\mathrm{S}_{0}\right)$ 在室温下 

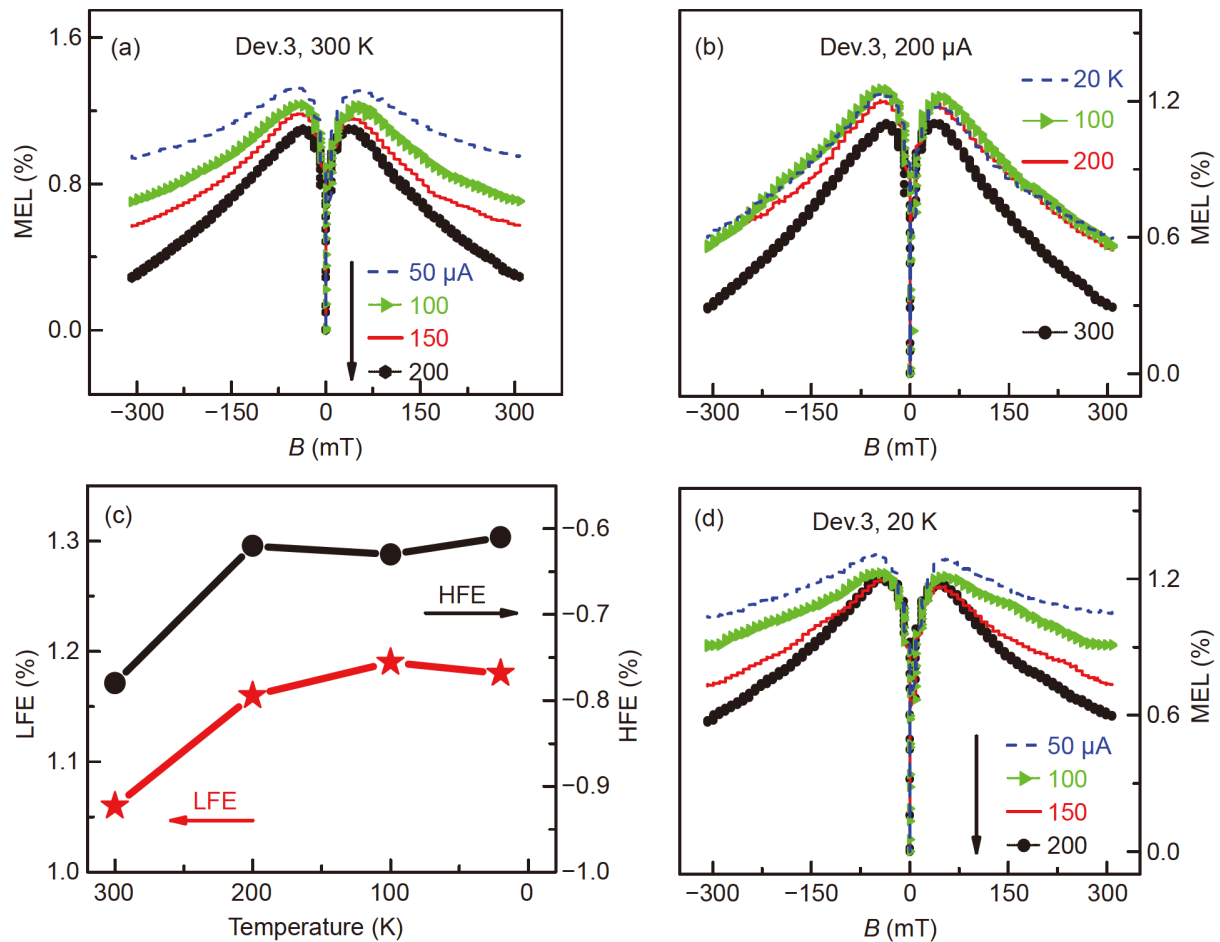

图 5 (网络版彩色)Dev.3的MEL曲线, LFE值和HFE值. (a) $300 \mathrm{~K}$ 下不同注人电流时的MEL曲线; (b) $200 \mu \mathrm{A}$ 下不同温度时的MEL曲线; (c) $200 \mu \mathrm{A}$ 下不同温度时的LFE值和HFE值; (d) 20 K下不同注人电流时的MEL曲线

Figure 5 (Color online) MEL curves, LFE and HFE values of Dev.3. (a) Current-dependent MEL curves at $300 \mathrm{~K}$; (b) temperature-dependent MEL curves at $200 \mu \mathrm{A}$; (c) temperature-dependent LFE and HFE values at $200 \mu \mathrm{A}$; (d) current-dependent MEL curves at $20 \mathrm{~K}$

具有较长的寿命. 随着温度从 $300 \mathrm{~K}$ 降低到 $20 \mathrm{~K}$ ，在激 基缔合物型器件中还发现了两种与激子型器件相反的 温度依赖关系，即激子型器件的TTA过程逐渐增强同 时LFE逐渐减小，而激基缔合物型器件的TTA过程逐 渐减弱同时LFE逐渐增大. 这是因为载流子迁移率的 降低阻碍了 $\mathrm{T}_{1}$ 与 $\mathrm{S}_{0}$ 相互作用形成 $\left(\mathrm{T}_{1}+\mathrm{S}_{0}\right)$, 从而减少了
$\left(\mathrm{T}_{1}+\mathrm{S}_{0}\right)$ 的数量; 当 $\left(\mathrm{T}_{1}+\mathrm{S}_{0}\right)$ 的数量减少, $\mathrm{TTA}$ 过程减弱, 从而器件的 $E L$ 和 $\Delta E L$ 都减小; 又因为EL减小得比 $\Delta E L$ 更快, 所以LFE增大. 本研究工作利用MEL这个无接触 并且无损害的探测性工具研究了激基缔合物型OLEDs 中激发态演化的微观机制，并对这些微观机制提出了 一些理解.

\section{参考文献}

1 Förster T, Kasper K. Ein konzentrationsumschlag der fluoreszenz. Z Physikalische Chem, 1954, 1: 275-277

2 Kim Y, Bouffard J, Kooi S E, et al. Highly emissive conjugated polymer excimers. J Am Chem Soc, 2005, 127: 13726-13731

3 Gao Y, Liu H C, Zhang S T, et al. Excimer formation and evolution of excited state properties in discrete dimeric stacking of an anthracene derivative: A computational investigation. Phys Chem Chem Phys, 2018, 20: 12129-12137

4 Kalinowski J, Cocchi M, Virgili D, et al. Mixing of excimer and exciplex emission: A new way to improve white light emitting organic electrophosphorescent diodes. Adv Mater, 2007, 19: 4000-4005

5 Hu B, Yan L, Shao M. Magnetic-field effects in organic semiconducting materials and devices. Adv Mater, 2009, 21: 1500-1516

6 Chen P, Xiong Z H, Peng Q M, et al. Magneto-electroluminescence as a tool to discern the origin of delayed fluorescence: Reverse intersystem crossing or triplet-triplet annihilation? Adv Opt Mater, 2014, 2: 142-148

7 Yuan P S, Qiao X F, Yan D H, et al. Magnetic field effects on the quenching of triplet excitons in exciplex-based organic light emitting diodes. J Mater Chem C, 2018, 6: 5721-5726

$8 \mathrm{Xu}$ J, Tang X T, Deng J Q, et al. Understanding the mechanisms of light emission from DCJTB charge-transfer states in OLEDs using organic magnetic field effects (in Chinese). Chin Sci Bull, 2019, 64: 694-704 [许静, 汤仙童, 邓金秋, 等. 利用有机磁效应探究基于DCJTB电荷转移态 发光器件的微观机制. 科学通报, 2019, 64: 694-704] 
9 Liu D Y, Chen L X, Xiang J, et al. Triplet induced competition between scattering and dissociation process in exciton-charge reaction (in Chinese). Chin Sci Bull, 2017, 62: 3885-3893 [刘冬玉, 陈历相, 向杰, 等. 三重态激子浓度对激子-电荷反应中散射和解离过程的调控. 科学通报, 2017, 62: 3885-3893]

10 Joshi G, Teferi M Y, Miller R, et al. High-field magnetoresistance of organic semiconductors. Phys Rev Appl, 2018, 10: 024008

11 Crooker S A, Liu F, Kelley M R, et al. Spectrally resolved hyperfine interactions between polaron and nuclear spins in organic light emitting diodes: Magneto-electroluminescence studies. Appl Phys Lett, 2014, 105: 153304

12 Peng Q M, Li W J, Zhang S T, et al. Evidence of the reverse intersystem crossing in intra-molecular charge-transfer fluorescence-based organic light-emitting devices through magneto-electroluminescence measurements. Adv Opt Mater, 2013, 1: 362-366

13 Xiang J, Chen Y B, Yuan D, et al. Abnormal temperature dependent behaviors of intersystem crossing and triplet-triplet annihilation in organic planar heterojunction devices. Appl Phys Lett, 2016, 109: 103301

14 Du K, Zhang K, Dong S, et al. Visualization of a ferromagnetic metallic edge state in manganite strips. Nat Commun, 2015, 6: 6179

15 Yao X N, Duan Q Q, Tong J W, et al. Magnetoresistance effect and the applications for organic spin valves using molecular spacers. Materials, 2018, 11: 721

16 Liu F L, Kelley M R, Crooker S A, et al. Magnetoelectroluminescence of organic heterostructures: Analytical theory and spectrally resolved measurements. Phys Rev B, 2014, 90: 235314

17 Conwell E M. Excimers in poly(phenylene vinylene) and its derivatives. Synth Met, 1997, 85: 995-999

18 Sukhodola A A. Annihilation delayed fluorescence of indole and its derivatives in aqueous solution. J Appl Spectrosc, 2017, 84: 954

19 Cai J J, Lim E C. Time-resolved emission studies of intermolecular triplet excimer formation in fluid solutions of dibenzopyrrole, dibenzofuran, and dibenzothiophene. J Chem Phys, 1992, 97: 3892-3896

20 Locke R J, Lim E C. Orientational effect on intramolecular triplet excimer formation in (1,n)-dinaphthylalkanes. J Phys Chem, 1989, 93: 60176019

$21 \mathrm{Xu} \mathrm{T}$, Li W L, Gao X C, et al. Temperature and exciton concentration induced excimer emission of 4,4'-bis(4"-triphenylsilyl)phenyl-1,1'binaphthalene and application for sunlight-like white organic light-emitting diodes. Nanoscale Res Lett, 2016, 11: 379

22 Sims M, Bradley D D C, Ariu M, et al. Understanding the origin of the $535 \mathrm{~nm}$ emission band in oxidized poly(9,9-dioctylfluorene): The essential role of inter-chain/inter-segment interactions. Adv Funct Mater, 2004, 14: 0305149

23 Qiao X F, Yuan P S, Ma D G, et al. Electrical pumped energy up-conversion: A non-linear electroluminescence process mediated by triplet-triplet annihilation. Org Electron, 2017, 46: 1-6

24 Zhao B, Zhang H, Miao Y Q, et al. Low turn-on voltage and low roll-off rare earth europium complex-based organic light-emitting diodes with exciplex as the host. J Mater Chem C, 2017, 5: 12182-12188

25 Friederich P, Gómez V, Sprau C, et al. Rational in silico design of an organic semiconductor with improved electron mobility. Adv Mater, 2017, 29: 1703505

26 Lorente A, Pingel P, Liaptsis G, et al. Modulation of ambipolar charge transport characteristics in side-chain polystyrenes as host materials for solution processed OLEDs. Org Electron, 2017, 41: 91-99

27 Holmes R J, D’Andrade B W, Forrest S R, et al. Efficient, deep-blue organic electrophosphorescence by guest charge trapping. Appl Phys Lett, 2003, 83: 3818-3820

28 Zhao Y L, Guo Q X, Li X P, et al. Influence of the linkage mode and D/A ratio of carbazole/oxadiazole based host materials on phosphorescent organic light-emitting diodes. J Lumin, 2017, 188: 612-619

29 Chen Y M, Hung W Y, You H W, et al. Carbazole-benzimidazole hybrid bipolar host materials for highly efficient green and blue phosphorescent OLEDs. J Mater Chem, 2011, 21: 14971

30 Lee J H, Cheng S H, Yoo S J, et al. An exciplex forming host for highly efficient blue organic light emitting diodes with low driving voltage. Adv Funct Mater, 2015, 25: 361-366

31 Hung W Y, Fang G C, Lin S W, et al. The first tandem, all-exciplex-based WOLED. Sci Rep, 2014, 4: 05161

32 Tang X T, Pan R H, Deng J Q, et al. Analysis of trap-assisted triplet exciton quenching by magneto-conductance in rubrene-based organic lightemitting diodes (in Chinese). Chin Sci Bull, 2018, 63: 725-734 [汤仙童, 潘睿亨, 邓金秋, 等. 利用有机磁电导分析红荧烯发光器件中陷阱辅助 的三重态激子淬灭作用. 科学通报, 2018, 63: 725-734]

33 Pan R H, Tang X T, Hu Y Q, et al. Extraordinary magnetic field effects mediated by spin-pair interaction and electron mobility in thermally activated delayed fluorescence-based OLEDs with quantum-well structure. J Mater Chem C, 2019, 7: 2421-2429

34 Kimura S, Kusamoto T, Kimura S, et al. Magnetoluminescence in a photostable, brightly luminescent organic radical in a rigid environment. Angew Chem Int Ed, 2018, 57: 12711-12715 


\title{
Abnormal temperature dependence of triplet-triplet annihilation in excimer-based devices
}

\author{
Xi Zhao, Xiantong Tang, Ruiheng Pan, Jing Xu, Fenlan Qu \& Zuhong Xiong* \\ School of Physical Science and Technology, Southwest University, Chongqing 400715, China \\ * Corresponding author, E-mail: zhxiong@swu.edu.cn
}

Excimer is widely focused since Förster and Kasper discovered it in 1954. It is dimeric species formed by two identical molecules, which is associative in the excited electronic state and dissociative in the ground state. Usually, it has a long emission lifetime and exhibits red-shifted, broadened and structureless fluorescence emission relative to that of monomer, which leads to various applications, including laser devices, chemo-sensors and white-light organic light-emitting diodes (OLEDs). These applications are closely related to our life. Although excimer has many advantages, there are few probing tools about it and few reports that give a detailed understanding of it. More importantly, the microscopic mechanism of excimer is very significant for preparing photoelectric devices, improving emission efficiency of devices and its more applications. Thus, understanding the microscopic mechanisms of excimer is both challenging and needful for us. Recently, magneto-electroluminescence (MEL) has been shown to be a useful tool to understand the dynamics of the excited states within OLEDs. This technique without contact and harm uses an external magnetic field that can change the balance between singlet and triplet states and the EL intensity by affecting spin-related microcosmic processes within OLEDs. These microcosmic processes include intersystem crossing, reverse intersystem crossing, singlet fission and triplet-triplet annihilation (TTA). These microscopic processes possess their own characteristic MEL curves and are influenced by charge injection/recombination and the concentration and lifetime of excited states. As is known to all, the injection current used for an OLED can affect the concentration of excited states, while the working temperature of an OLED can influence the charge injection/recombination and the lifetime of the excited states. So, studying the current- and temperaturedependent MEL traces from OLEDs is an effective method to analyze intersystem crossing, reverse intersystem crossing, and TTA. Thus, microcosmic processes in the excimer-based OLEDs can be investigated by analyzing MEL curves of devices. Excimer-based OLEDs were fabricated, and their MEL curves were measured at different temperatures and injection currents. The MEL curves of excimer-based OLEDs are always composed of the low-field components $(|\boldsymbol{B}| \leqslant 50$ $\mathrm{mT})$ determined by intersystem crossing and the high-field components $(50 \mathrm{mT}<|\boldsymbol{B}| \leqslant 300 \mathrm{mT})$ governed by TTA. This indicates that TTA with delayed fluorescence always exists in the excimer-based devices at different temperatures and injection currents. It's noteworthy that, under a fixed injection current, the temperature dependence of TTA in the excimerbased OLEDs is contrary to that of exciton-based OLEDs. TTA in the exciton-based OLEDs happens at low temperature and enhances with decreasing temperature. But TTA in the excimer-based OLEDs happens at room temperature and weakens with decreasing temperature. This abnormal temperature dependence of TTA in the excimer-based OLEDs overcomes the disadvantage that TTA can only be used at low temperature to improve the luminescent efficiency of devices in the past. Based on the analysis of the structure, current-voltage-brightness characteristics and spectra of devices, the abnormal temperature dependence of TTA in the excimer-based OLEDs is related to the long lifetime of the excimer and the inhibition of excimer formation by low temperature. This work discloses the abnormal temperature dependence of TTA in the excimer-based OLEDs by investigating MEL curves of devices at different temperatures and may be helpful for improving the luminescent efficiency of OLEDs.

excimer, exciton, triplet-triplet annihilation, magneto-electroluminescence

doi: 10.1360/TB-2019-0111 